\section{Kidney \\ Blood Pressure Research}

Kidney Blood Press Res 2014;39:600-608

DOI: $10.1159 / 000368473$

Published online: December 15, 2014

Accepted: November 14, 2014

(C) 2014 S. Karger AG, Basel

www.karger.com/kbr

1423-0143/14/0396-0600\$39.50/0 NonCommercial 3.0 Unported license (CC BY-NC) (www.karger.com/OA-license), applicable to the online version of the article only. Distribution permitted for non-commercial purposes only.

\title{
Is There Association Between Changes in eGFR Value and the Risk of Permanent Type of Atrial Fibrillation? - Analysis of Valvular and Non-Valvular Atrial Fibrillation Population
}

\author{
Elzbieta Mlodawska ${ }^{a}$ Anna Tomaszuk-Kazberuk ${ }^{a}$ Paulina Lopatowska ${ }^{a}$ \\ Hanna Bachorzewska-Gajewska ${ }^{b, d}$ Jolanta Malyszkoc Slawomir Dobrzycki ${ }^{b}$ \\ Wlodzimierz Jerzy Musiala
}

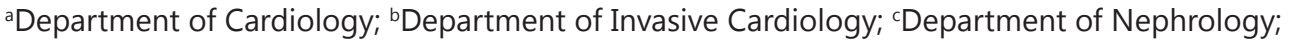
${ }^{\mathrm{d}}$ Department of Clinical Medicine, Medical University in Bialystok, Bialystok, Poland

\section{Key Words}

Valvular atrial fibrillation - Non-valvular atrial fibrillation • Kidney function • Estimated glomerular filtration rate

\begin{abstract}
Background/Aims: There are no data concerning renal function in population with valvular and non-valvular atrial fibrillation (AF). To assess renal function in patients with $A F$, the association between eGFR and AF perpetuation, in-hospital mortality. Methods: We studied 1523 patients with AF. Patients with chronic kidney disease (CKD) were compared to population with preserved renal function. Results: CKD was more frequently observed in patients with valvular $A F(p=0.009)$. In non-valvular AF patients eGFR $<60 \mathrm{ml} / \mathrm{min} . / 1,73 \mathrm{~m}^{2}$ had more often permanent $\operatorname{AF}(p<0.0001)$. In patients with CKD CHA $\mathrm{DS}_{2} \mathrm{VASc}$ score was $4.1 \pm 1.5$ and HAS-BLED score was $2.1 \pm 1.2$ and it was higher as compared to population with preserved renal function $(p<0.0001 \mathrm{vs}$ $p<0.0001)$. The odds of permanent AF in patients with non-valvular AF and CKD were increased 1.82 times $(\mathrm{OR}=1.82, \mathrm{p}<0.0001,95 \% \mathrm{CI}: 1.46-2.27)$. The odds of permanent AF in patients with valvular $A F$ and $C K D$ were not significantly increased(OR=1.46, $p=0.2,95 \% C I: 0.86-2.5)$. In nonvalvular $A F$, if eGFR decrease by $10 \mathrm{ml} / \mathrm{min}$, odds of permanent $A F$ are increased by $10 \%(O R=$ $1.1 p<0.0001,95 \% C I 1.05-1.15)$. In multivariate logistic regression, in non-valvular $A F$, odds of in-hospital death were higher for patients $>75$ years old $(O R=3.70, p=0.01,95 \% C I 1.33-10.28)$, with CKD $(O R=2.61, p=0.03,95 \% C I 1.09-6.23)$. The type of AF had no significant influence on in-hospital mortality(OR=0.71, $p=0.45,95 \% \mathrm{CIO} .30-1.70)$. Conclusions: $\mathrm{CKD}$ is more often observed in patients with valvular AF. In population with non-valvular AF decreased eGFR is associated with permanent type of AF and with higher $\mathrm{CHA}_{2} \mathrm{DS}_{2} \mathrm{VASC}$ and HAS-BLED score.
\end{abstract}




\section{Kidney \\ Blood Pressure Research}

Kidney Blood Press Res 2014;39:600-608

\begin{tabular}{l|l}
\hline DOI: $10.1159 / 000368473$ & $\begin{array}{l}\text { C 2014 S. Karger AG, Basel } \\
\text { Published onlIne: December 15, } 2014\end{array}$ \\
www.karger.com/kbr
\end{tabular}

Mlodawska/Tomaszuk-Kazberuk/Lopatowska et al.: eGFR Value and Type of Atrial FibrillationiIn Valvular and Non-Valvular Population

Among valvular AF patients there are no differences in type of $A F$ between patients with and without CKD. There is the correlation between CKD and AF perpetuation but only in nonvalvular population.

Copyright $\odot 2014$ S. Karger AG, Basel

\section{Introduction}

Atrial fibrillation (AF) is the most common cardiac arrhythmia, occurring in 1\%-2\% of the general population and is a well-known risk factor of cardiovascular morbidity and mortality $[1,2]$. AF frequently occurs in renal failure population and ranges from $19 \%$ to $24 \%$ rising to $27 \%$ in patients with end-stage renal disease [3, 4]. Several studies have implicated AF as a contributing factor in CKD and cardiovascular events $[3,5]$.

On the other hand there are few studies concerning renal function in population with AF $[6,7]$. Moreover influence of renal impairment on in-hospital mortality in patients with valvular and non-valvular AF is not defined. It is worth noting that renal function has not been investigated in patients with valvular atrial fibrillation so far. Although the type of $\mathrm{AF}$ does not influence mortality and the risk of stroke in general population with AF, the significance of type AF in population with renal failure is also unknown.

The aim of the present study was to assess renal function in patients with AF, the association between eGFR (estimated glomerular filtration rate) value and the prevalence of certain types of $\mathrm{AF}$ in valvular and non-valvular $\mathrm{AF}$ patients. We also investigated the influence of renal function on in-hopital mortality in AF population both valvular and nonvalvular.

\section{Material and Methods}

\section{Study population}

We retrospectively studied 1523 patients with the diagnosis of AF hospitalized in the Department of Cardiology and the Department of Invasive Cardiology in years 2012-2014. The study protocol conformed to the ethical guidelines of the 1975 Declaration of Helsinki, and was approved by the local ethics committee. At the study entry medical history was recorded, all patients underwent physical examination, resting ECG, routine transthoracic echocardiography.

The patients were subsequently divided into two groups according to the presence of valvular or nonvalvular atrial fibrillation. Clinical characteristics, type of AF and renal function were compared between the two groups. Patients with chronic kidney disease were compared to population with preserved renal function in each group separately. The primary end-point was in-hospital mortality.

\section{Definition of Valvular Atrial Fibrillation}

We define valvular atrial fibrillation according to recent 2014 AHA/ACC/HRS Guidelines for the Management of Patients with Atrial Fibrillation [8] as AF in rheumatic mitral stenosis, a mechanical or bioprosthetic heart valve or valve repair. We also consider as valvular AF patients with aortic stenosis or insufficiency and mitral insufficiency who need a surgical procedure, as in three major AF trials (RE-LY, ROCKET AF, and ARISTOTLE trials) [9-11].

Assessment of renal function

Baseline laboratory values were obtained on admission. Renal function was assessed using glomerular filtration rate (GFR) estimated by MDRD equation: estimated GFR = 186x (serum creatinine level in mg/ $\mathrm{dl})^{-1.154} \mathrm{X}$ age (in years) ${ }^{-0.203}$. For women the product of this equation was multiplied by a correction factor of $0.742[12,13]$. The cut off value of eGFR was $60 \mathrm{ml} / \mathrm{min} . / 1,73 \mathrm{~m}^{2}$. 


\section{Kidney Blood Pressure Research}

\section{Kidney Blood Press Res 2014;39:600-608}

\begin{tabular}{l|l}
\hline DOI: $10.1159 / 000368473$ & C) 2014 S. Karger AG, Basel \\
Publisned ontIne: December 15, 2014 & www.karger.com/kbr
\end{tabular} www.karger.com/kbr

Mlodawska/Tomaszuk-Kazberuk/Lopatowska et al.: eGFR Value and Type of Atrial FibrillationiIn Valvular and Non-Valvular Population

Echocardiographic analysis

Left ventricular ejection fraction (LVEF) was assessed in transthoracic echocardiography using the modified biplane Simpson's method (Philips Ultrasound System Sonos 5500, equipped for harmonic imaging with a $3.6 \mathrm{MHz}$ transducer) and was derived in accordance with the recommendations of the European Society of Echocardiography [14].

\section{Statistical analysis}

Data are expressed as means and standard deviations (SD). Relative frequencies are used to present categorical variables. The Student's t test, the Wilcoxon rank-sum test and chi-square test was used for statistical analysis where applicable. Logistic regression was used to test associations between variables and outcomes. Multinomial logistic regression was used to evaluate the association between variables and in-hospital mortality. A p value of less than 0.05 was considered as statistically significant. The statistic software, StataIC (data analysis of statistical software) version 13, was used.

\section{Results}

\section{Baseline characteristics}

A total of 1523 patients with AF (668 women, 45\%; mean age $71 \pm 11$ years) were included in the analysis. Paroxysmal AF was present in 43\% ( $\mathrm{n}=656)$, persistent in $16 \%$ $(n=249)$, permanent in $40 \%(n=616)$ of the patients. Valvular AF was observed in $16 \%$ $(\mathrm{n}=237)$ and among them aortic valvular disease in $33 \%(\mathrm{n}=78)$ and mitral valve disease in $45 \%(n=107)$. Hypertension was present in $73 \%(n=1119)$, diabetes in $27 \%(n=408)$, CKD in $31 \%(n=475)$, ischemic heart disease (IHD) in 46\% $(n=693)$ and chronic heart failure (CHF) in $57 \%(n=875)$ of the patients. The mean LVEF assessed by echocardiography was $46 \pm 14 \%$, mean left atrium diameter was $46 \pm 8 \mathrm{~mm}$.

$\mathrm{CHA}_{2} \mathrm{DS}_{2}$ VASc score in the population with non-valvular AF was $3.5 \pm 1.7$ and HAS-BLED score was $1.8 \pm 1.1$.

In the study population the in-hospital mortality was $2 \%(n=31)$. Clinical characteristics of the population is shown in Table 1 .

\section{Comparison of patients with valvular and non-valvular atrial fibrillation}

Patients with valvular AF were more frequently females $(\mathrm{p}=0.01)$ and had more often permanent $A F(p<0.0001)$, heart failure $(p<0.0001)$ and anaemia $(p=0.0004)$.

The mean eGFR evaluated by MDRD formula was $74 \pm 26 \mathrm{ml} / \mathrm{min} . / 1,73 \mathrm{~m}^{2}$ in patients with non-valvular $\mathrm{AF}$ and $72 \pm 27 \mathrm{ml} / \mathrm{min} . / 1,73 \mathrm{~m}^{2}$ in patients with valvular AF. Chronic kidney disease was more frequently observed in patients with valvular AF $(p=0.009)$. Previous stroke/TIA was observed with similar frequency $(\mathrm{p}=0.89)$. Comparison between the two groups is shown in Table 1.

\section{Non-valvular AF and chronic kidney disease}

In population with non-valvular AF patients with moderately and severely decreased eGFR $\left(<60 \mathrm{ml} / \mathrm{min} . / 1,73 \mathrm{~m}^{2}\right)$ tended to be older $(\mathrm{p}<0.0001)$, they were more frequently females $(p=0.001)$ and had more often permanent AF $(p<0.0001)$, CHF $(p=0.002)$, diabetes $(p=0.0004)$, anaemia $(p<0.0001)$, history of myocardial infarction (MI) $(p=0.005)$ and CABG $(p=0.01)$. Previous stroke/TIA and IHD was observed with similar frequency $(p=0.13$, $\mathrm{p}=0.57$, respectively).

In patients with chronic kidney disease $\mathrm{CHA}_{2} \mathrm{DS}_{2} \mathrm{VASc}$ score was $4.1 \pm 1.5$ and HAS-BLED score was $2.1 \pm 1.2$ and it was significantly higher as compared to population with preserved renal function $(\mathrm{p}<0.0001, \mathrm{p}<0.0001$, respectively). The use of oral anticoagulation did not differ between the two groups $(\mathrm{p}=0.08)$. 


\section{Kidney \\ Blood Pressure Research}

Table 1. Clinical characteristics of the population and comparison between valvular and non-valvular atrial fibrillation

\begin{tabular}{|c|c|c|c|c|}
\hline & $\begin{array}{c}\text { All patients } \\
\mathrm{n}=1523\end{array}$ & $\begin{array}{c}\text { Valvular } \\
\mathrm{AF} n=237\end{array}$ & $\begin{array}{c}\text { Non- } \\
\text { valvular AF } \\
\mathrm{n}=1286 \\
\end{array}$ & p-value \\
\hline Females (\%) & $685(45)$ & $126(53)$ & $566(44)$ & 0.01 \\
\hline Age (years) & $71 \pm 11$ & $72 \pm 9$ & $71 \pm 11$ & 0.2 \\
\hline Age $\geq 75$ years $(\%)$ & $655(43)$ & $107(45)$ & $540(42)$ & 0.4 \\
\hline Body mass index $(\mathrm{kg} / \mathrm{m} 2)$ & $29 \pm 5$ & $27 \pm 4$ & $29 \pm 5$ & $<0.0001$ \\
\hline Heart rate (beats /min) & $81 \pm 25$ & $83 \pm 24$ & $81 \pm 24$ & 0.2 \\
\hline Systolic blood pressure (mmHg) & $130 \pm 23$ & $127 \pm 25$ & $130 \pm 22$ & 0.008 \\
\hline $\mathrm{eGFR}\left(\mathrm{ml} / \mathrm{min} / 1.73 \mathrm{~m}^{2}\right)$ & $74 \pm 26$ & $72 \pm 27$ & $74 \pm 26$ & 0.3 \\
\hline Left atrial diameter (mm) & $46 \pm 8$ & $50 \pm 8$ & $45 \pm 7$ & $<0.0001$ \\
\hline Ejection fraction (\%) & $46 \pm 14$ & $42 \pm 15$ & $46 \pm 14$ & $<0.0001$ \\
\hline CHA2-DS2-VASc score * & & & $3.5 \pm 1.7$ & \\
\hline HAS-BLED score * & & & $2.4 \pm 1.1$ & \\
\hline Valvular AF (\%) & $244(16)$ & & & \\
\hline \multicolumn{5}{|l|}{ Type of AF } \\
\hline Paroxysmal (\%) & $655(43)$ & $69(29)$ & $592(46)$ & $<0.0001$ \\
\hline Persistent (\%) & $244(16)$ & $33(14)$ & $180(14)$ & 0.4 \\
\hline Permanent (\%) & $609(40)$ & $135(57)$ & $476(37)$ & $<0.0001$ \\
\hline Hypertension (\%) & $1112(73)$ & $154(65)$ & $964(75)$ & $<0.0001$ \\
\hline Diabetes mellitus (\%) & $411(27)$ & $59(25)$ & $347(27)$ & 0.4 \\
\hline Coronary artery disease (\%) & $701(46)$ & $90(38)$ & $604(47)$ & 0.007 \\
\hline Chronic heart failure (\%) & $868(57)$ & $182(77)$ & $694(54)$ & $<0.0001$ \\
\hline Chronic kidney disease (\%) & $472(31)$ & $69(29)$ & $231(18)$ & 0.0003 \\
\hline COPD (\%) & $107(7)$ & $19(8)$ & $90(7)$ & 0.4 \\
\hline Anaemia (\%) & $442(29)$ & $90(38)$ & $347(27)$ & 0.0004 \\
\hline Previous myocardial infarction (\%) & $274(18)$ & $28(12)$ & 244 (19) & 0.01 \\
\hline Previous TIA/stroke (\%) & $152(10)$ & $24(10)$ & $129(10)$ & 0.9 \\
\hline Previous PCI (\%) & $137(9)$ & $12(5)$ & $129(10)$ & 0.02 \\
\hline Previous CABG (\%) & $91(6)$ & $26(11)$ & $64(5)$ & $<0.0001$ \\
\hline In-hospital mortality (\%) & $30(2)$ & $7(3)$ & $26(2)$ & 0.1 \\
\hline
\end{tabular}

Valvular AF and chronic kidney disease

Patients with valvular AF and moderately and severely decreased eGFR $(<60 \mathrm{ml} /$ $\left.\min . / 1,73 \mathrm{~m}^{2}\right)$ tended to be older $(\mathrm{p}=0.03)$. There were no significant differences between patients with and without CKD.

Differences in frequency between valvular and non-valvular AF according to the stage of CKD are shown on Figure 1.

Renal function and type of atrial fibrillation in valvular and non-valvular $A F$

The odds of permanent AF in patients with non-valvular AF and CKD were increased 1.82 times as compared to patients with preserved renal function $(\mathrm{OR}=1.82, \mathrm{p}<0.0001,95 \%$ CI: 1.46-2.27). The odds of permanent AF in patients with valvular AF and CKD were not significantly increased as compared to patients with preserved renal function $(O R=1.46$, $\mathrm{p}=0.2,95 \%$ CI: 0.86-2.5).

In non-valvular AF patients, if eGFR decrease by $10 \mathrm{ml} / \mathrm{min}$, odds of permanent $\mathrm{AF}$ are increased by $10 \%(\mathrm{OR}=1.1$, p<0.0001, 95\% CI 1.05- 1.15$)$. 


\section{Kidney Blood Pressure Research}

Fig. 1. Differences in frequency between valvular and non-valvular $\mathrm{AF}$ according to the stage of CKD.

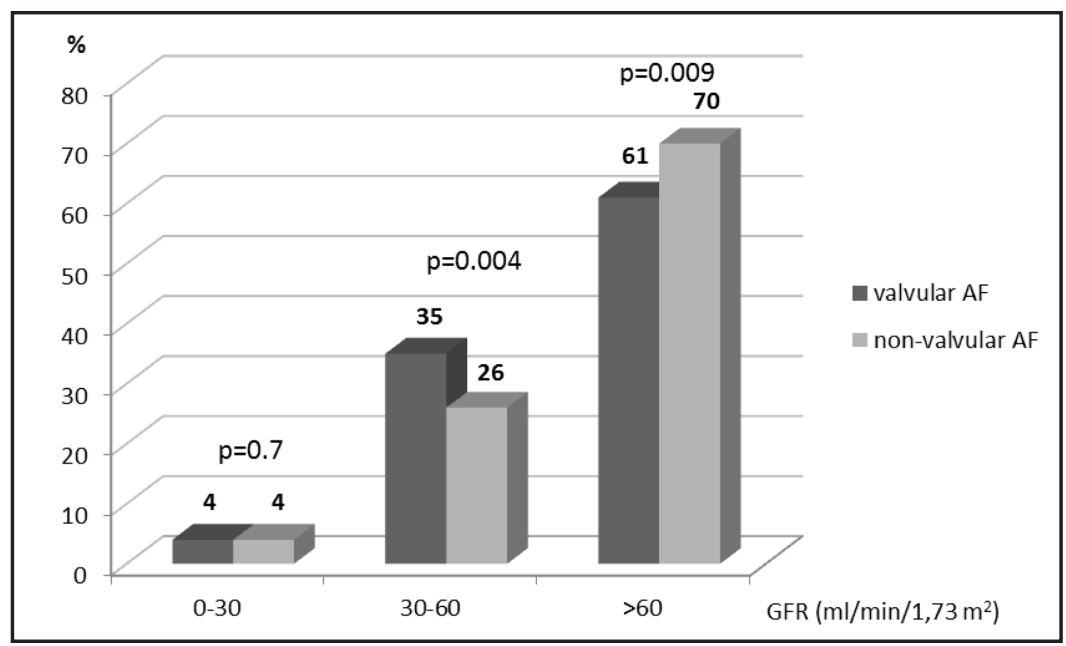

Fig. 2. Odds of permanent AF according to the stage of CKD in patients with valvular and non-valvular AF.

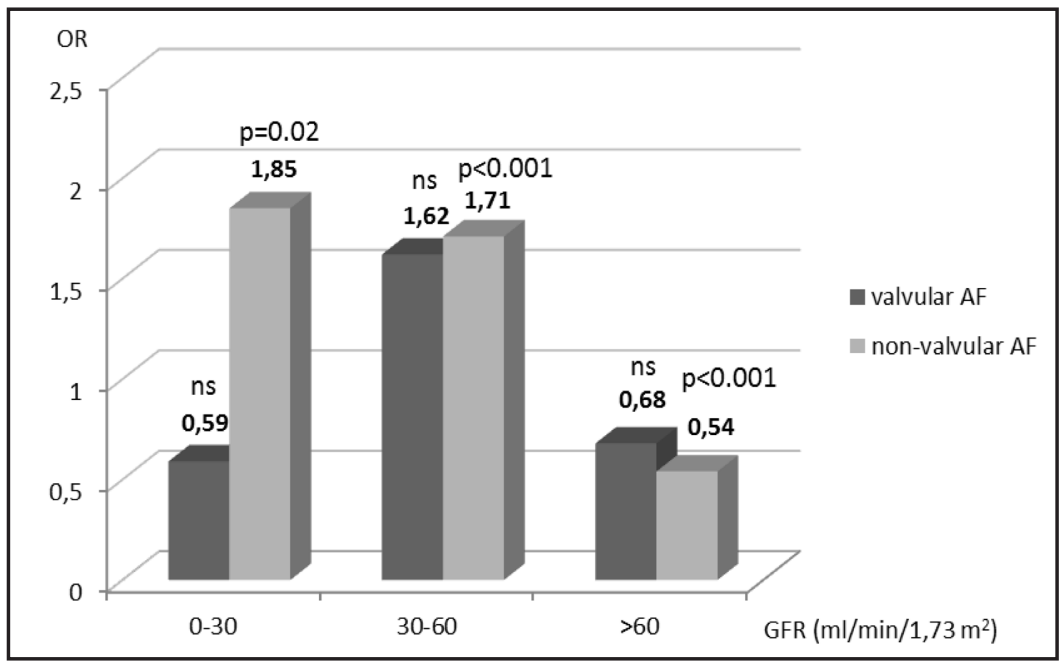

Odds of permanent AF according to the stage of CKD in patients with valvular and nonvalvular AF are shown on Figure 2.

Among patients who received NOAC, 13\% had reduced dose of NOAC, $3 \%$ were given NOAC despite eGFR $<30 \mathrm{ml} / \mathrm{min} / 1.73 \mathrm{~m}^{2}$.

In-hospital mortality

The in-hospital mortality did not significantly differ between patients with valvular and non-valvular AF ( $\mathrm{p}=0.1)$.

In the logistic regression model odds of in-hospital death for patients with non-valvular AF were 2.7 times higher for patients with CKD than for patients with preserved renal function ( $\mathrm{p}=0.06,95 \% \mathrm{CI}$ : 1.34-5.61). In valvular $\mathrm{AF}$ patients impaired renal function did not increase odds of in-hospital death ( $p=0.96,95 \%$ CI: 0.22-4.12). The type of AF had no significant influence on in-hospital mortality in both valvular $\mathrm{AF}$ and non-valvular $\mathrm{AF}$ (OR= 1.27, $\mathrm{p}=0.8,95 \%$ CI 0.29-5.43, OR=1.21, $\mathrm{p}=0.6,95 \%$ CI 0.59-2.49, respectively).

When stratified by eGFR $\left(<60 \mathrm{ml} / \mathrm{min} . / 1,73 \mathrm{~m}^{2}\right.$ and $\left.>60 \mathrm{ml} / \mathrm{min} . / 1,73 \mathrm{~m}^{2}\right)$, in population with CKD the type of AF had also no impact on in-hospital mortality in both valvular AF and non-valvular AF $(\mathrm{OR}=0.28, \mathrm{p}=0.32,95 \% \mathrm{CI} 0.02-3.27, \mathrm{OR}=0.81, \mathrm{p}=0.7,95 \% \mathrm{CI} 0.278-2.40$, respectively).

In multivariate logistic regression, in non-valvular $\mathrm{AF}$ patients, odds of in-hospital death were higher for patients $>75$ years old $(\mathrm{OR}=3.70, \mathrm{p}=0.01,95 \% \mathrm{CI} 1.33-10.28)$, with 


\section{Kidney Blood Pressure Research}

Mlodawska/Tomaszuk-Kazberuk/Lopatowska et al.: eGFR Value and Type of Atrial FibrillationiIn Valvular and Non-Valvular Population

Table 2. Multivariate logistic regression model

\begin{tabular}{lccc}
\hline Odds of in-hospital death in non-valvular AF patients & OR & $95 \%$ CI & p value \\
\hline Age $\geq 75$ years & 3.70 & $1.33-10.28$ & 0.01 \\
Chronic kidney disease & 2.61 & $1.09-6.23$ & 0.03 \\
Chronic heart failure & 2.74 & $1.01-7.46$ & 0.049 \\
Type of AF & 0.71 & $0.30-1.70$ & 0.45 \\
\hline Odds of in-hospital death in valvular AF patients & OR & $95 \%$ CI & p value \\
\hline Age $\geq 75$ years & 9.75 & $1.16-82.16$ & 0.04 \\
Chronic kidney disease & 0.71 & $0.16-3.19$ & 0.66 \\
Chronic heart failure & 2.54 & $0.29-21.88$ & 0.4 \\
Type of AF & 0.95 & $0.21-4.18$ & 0.94 \\
\hline OR - Odds ratio; CI - confidence interval. & & &
\end{tabular}

CKD (OR=2.61, $\mathrm{p}=0.03,95 \%$ CI 1.09-6.23) and CHF (OR=2.74, $\mathrm{p}=0.049,95 \%$ CI 1.01-7.46). The type of AF had no significant influence on in-hospital mortality $(\mathrm{OR}=0.71, \mathrm{p}=0.45,95 \% \mathrm{CI}$ $0.30-1.70$ ) (Table 2).

In multivariate logistic regression, in valvular AF patients, odds of in-hospital death were higher for patients $>75$ years old (OR=9.75, $\mathrm{p}=0.04,95 \% \mathrm{CI} 1.16-82.16)$. The type of $\mathrm{AF}, \mathrm{CKD}$ and CHF had no significant influence on in-hospital mortality (OR=0.95, $\mathrm{p}=0.94$, 95\%CI 0.21-4.18, OR=0.71, $\mathrm{p}=0.66,95 \% \mathrm{CI} 0.16-3.19, \mathrm{OR}=2.54, \mathrm{p}=0.4,95 \% \mathrm{CI} 0.29-21.88$, respectively) (Table 2 ).

\section{Discussion}

The current study is a one of few studies on renal function in AF patients and the first one which refers to valvular AF population. We showed that CKD is diagnosed in almost every third patient with $\mathrm{AF}$ and is significantly more frequently observed in patients with valvular $\mathrm{AF}$

Chronic kidney disease has well-established link with AF. The prevalence of AF in CKD patients was even 15 times higher than in population from the Framingham Heart Study [15]. Recent population-based studies demonstrated the relationship between frequency of $\mathrm{AF}$ and the stage of CKD [16-19]. In the Atherosclerosis Risk in Communities study (ARIC) hazard ratio of developing new onset $\mathrm{AF}$ was 3.2 times higher in patients with severely impaired renal function. Moreover, the increased risk of $\mathrm{AF}$ was observed even in patients with relatively preserved renal function (eGFR 60-90ml/min) [17]. Similar data was observed in population-based study of U.S. adults - REGARDS, where regardless of severity, CKD was associated with an increased prevalence of AF [16]. Interestingly, the ARIC study reported 2 -fold increase in risk of AF in patients with microalbuminuria [17].

According to the literature CKD is present in $10 \%-15 \%$ of AF patients [20]. Renal failure may increase the risk of AF-related cardiovascular complications [20]. In the multicenter randomized AMADEUS trial, that compare renal function and outcomes in anticoagulated patients with non-valvular AF, patients with CKD were older, they were more frequently females, had more often chronic heart failure, coronary artery disease, history of stroke/ TIA, and higher $\mathrm{CHA}_{2} \mathrm{DS}_{2}$ VASc and HAS-BLED score [6]. In our population with non-valvular AF decreased eGFR was associated with chronic heart failure, diabetes, anaemia, higher $\mathrm{CHA}_{2} \mathrm{DS}_{2}$ VASc and HAS-BLED score. We did not observe more frequently coronary artery disease and history of stroke/TIA in patients with CKD. However, they had more often history of MI and CABG.

So far in most of the studies the association between $\mathrm{AF}$ and renal function has been investigated in patients with non-valvular AF. The current study is the first one which refers 


\section{Kidney Blood Pressure Research}

Kidney Blood Press Res 2014;39:600-608

\begin{tabular}{l|l}
\hline DOI: $10.1159 / 000368473$ & C) 2014 S. Karger AG, Basel \\
Published onIIne: December 15, 2014 & www.karger.com/kbr
\end{tabular}

Mlodawska/Tomaszuk-Kazberuk/Lopatowska et al.: eGFR Value and Type of Atrial FibrillationiIn Valvular and Non-Valvular Population

to valvular AF patients. We showed that CKD is more often observed in this population. However, among valvular AF patients there were no significant differences in clinical characteristics and type of AF between patients with and without CKD. Furthermore, the inhospital mortality was similar in both groups.

The explanation of these findings is unclear. Valvular AF is connected with completely different, usually severely ill population than non-valvular AF. Although valvular AF is less common in industrialized countries than non-valvular type we are of interest in this field because valvular $\mathrm{AF}$ is still relatively frequent and valve problems lead to progressive heart failure and often requires surgical or trancutaneous intervention [21,22].

Decision-making for intervention is complex, since valve disease is often seen at an older age and, as a consequence, there is a higher frequency of comorbidity, contributing to increased risk of intervention [23].

Whether renal impairment influence the development of different types of AF (paroxysmal, persistent, permanent) is also unclear. Furthermore, there is no data demonstrating this relationship in non-valvular as well as valvular AF patients. The observations from our study showed that impaired renal function is associated with permanent type of AF only in non-valvular AF patients. The odds of permanent AF in patients with CKD were increased 1.82 times as compared to patients with preserved renal function. The reduction of eGFR by $10 \mathrm{ml} / \mathrm{min}$ increased the odds of permanent AF by $10 \%$. However, in valvular AF patients there were no differences in the type of AF between patients with $\mathrm{CKD}$ and those with preserved renal function. Therefore the influence of renal disease on AF perpetuation should be assessed in a prospective study in the future.

There is an increase in cardiovascular mortality as kidney function declines. Anavekar et al. reported that each 10 unit reduction of eGFR was associated with a $10 \%$ increase in the relative risk of death or non-fatal cardiovascular complications [24]. Several studies have implicated AF as a contributing factor in CKD and cardiovascular events. Nakagawa et al. reported that long-term mortality, cardiac events and stroke risk were 8 times higher in nonvalvular AF patients with decreased eGFR $\left(<60 \mathrm{ml} / \mathrm{min} . / 1,73 \mathrm{~m}^{2}\right)$ [25]. Furthermore a strong association between $\mathrm{AF}$ and mortality has been found in patients with end-stage renal disease. Genovesi et al. reported data from 5 dialysis centers in Italy where AF was independently associated with 65\% increase in mortality [26]. However, whether renal impairment has different influence on in-hospital mortality in patients with valvular and non-valvular AF is less well defined. In our study the in-hospital mortality was significantly higher only in nonvalvular AF patients with CKD. In valvular AF patients there was no significant difference in in-hospital mortality between CKD patients and those with preserved renal function.

\section{Limitations}

We have no current data on treatment strategies for the prevention of AF. Out-patient centers did not contribute for this registry and patients cared for by general practitioners were not included. This has to be taken into account when extrapolating from these data to the general population.

\section{Conclusions}

CKD is a frequent diagnosis in patients with $\mathrm{AF}$ and is significantly more often observed in patients with valvular AF. In population with non-valvular AF decreased eGFR is associated with permanent type of AF and with many accompanying diseases which are reflected by higher $\mathrm{CHA}_{2} \mathrm{DS}_{2}$ VASc and HAS-BLED score. While among valvular AF patients there are no significant differences in clinical characteristics and type of AF between patients with and without CKD. There is the correlation between CKD and AF perpetuation but only in nonvalvular population. The in-hospital mortality is similar in both groups. 


\section{Kidney \\ Blood Pressure Research}

Kidney Blood Press Res 2014;39:600-608

\begin{tabular}{l|l}
\hline DOI: $10.1159 / 000368473$ & (c) 2014 S. Karger AG, Basel
\end{tabular}

Published onIIne: December 15, 2014

www.karger.com/kbr

Mlodawska/Tomaszuk-Kazberuk/Lopatowska et al.: eGFR Value and Type of Atrial FibrillationiIn Valvular and Non-Valvular Population

\section{Disclosure Statement}

None of the authors identify any conflict of interests.

\section{Acknowledgements}

Our study was supported by funds from Leading National Research Center in Bialystok, Poland (KNOW).

\section{References}

1 Camm AJ, Lip GY, De Caterina R, Savelieva I, Atar D, Hohnloser SH, Hindricks G, Kirchhof P; ESC Committee for Practice Guidelines (CPG): 2012 focused update of the ESC Guidelines for the management of atrial fibrillation: an update of the 2010 ESC Guidelines for the management of atrial fibrillation. Developed with the special contribution of the European Heart Rhythm Association. Eur Heart J 2012;33:2719-2747.

2 Nimmo C, Wright M, Goldsmith D: Management of atrial fibrillation in chronic kidney disease: double trouble. Am Heart J 2013;166:230-239.

-3 Herzog CA, Asinger RW, Berger AK, Charytan DM, Díez J, Hart RG, Eckardt KU, Kasiske BL, McCullough PA, Passman RS, DeLoach SS, Pun PH, Ritz E: Cardiovascular disease in chronic kidney disease: a clinical update from Kidney Disease: Improving Global Outcomes (KDIGO). Kidney Int 2011;80:572-586.

-4 Wetmore JB, Mahnken JD, Rigler SK, Ellerbeck EF, Mukhopadhyay P, Spertus JA, Hou Q Shireman TI: The prevalence of and factors associated with chronic atrial fibrillation in Medicare/Medicaid-eligible dialysis patients. Kidney Int 2012;81:469-476.

-5 Weiner DE, Tabatabai S, Tighiouart H, Elsayed E, Bansal N, Griffith J, Salem DN, Levey AS, Sarnak MJ: Cardiovascular outcomes and all-cause mortality: exploring the interaction between CKD and cardiovascular disease. Am J Kidney Dis 2006;48:392-401.

6 Apostolakis S, Guo Y, Lane DA, Buller H, Lip GY: Renal function and outcomes in anticoagulated patients with non-valvular atrial fibrillation: the AMADEUS trial. Eur Heart J 2013;34:3572-3579.

7 Fu S, Liu T, Luo L, Ye P: Different types of atrial fibrillation, renal function, and mortality in elderly Chinese patients with coronary artery disease. Clin Interv Aging 2014;9:301-308.

$>8$ January CT, Wann LS, Alpert JS, Calkins H, Cleveland JC Jr, Cigarroa JE, Conti JB, Ellinor PT, Ezekowitz MD, Field ME, Murray KT, Sacco RL, Stevenson WG, Tchou PJ, Tracy CM, Yancy CW: 2014 AHA/ACC/HRS Guideline for the Management of Patients With Atrial Fibrillation: A Report of the American College of Cardiology/American Heart Association Task Force on Practice Guidelines and the Heart Rhythm Society. J Am Coll Cardiol 2014;64:2246-2280.

-9 Connolly SJ, Ezekowitz MD, Yusuf S, Eikelboom J, Oldgren J, Parekh A, Pogue J, Reilly PA, Themeles E, Varrone J, Wang S, Alings M, Xavier D, Zhu J, Diaz R, Lewis BS, Darius H, Diener HC, Joyner CD, Wallentin L; RE-LY Steering Committee and Investigators: Dabigatran versus warfarin in patients with atrial fibrillation. N Engl J Med 2009;361:1139-1151.

10 Patel MR, Patel MR, Mahaffey KW, Garg J, Pan G, Singer DE, Hacke W, Breithardt G, Halperin JL, Hankey GJ, Piccini JP, Becker RC, Nessel CC, Paolini JF, Berkowitz SD, Fox KA, Califf RM; ROCKET AF Investigators: Rivaroxaban versus warfarin in nonvalvular atrial fibrillation. N Engl J Med 2011;365:883-891.

-11 Granger CB, Alexander JH, McMurray JJ, Lopes RD, Hylek EM, Hanna M, Al-Khalidi HR, Ansell J, Atar D, Avezum A, Bahit MC, Diaz R, Easton JD, Ezekowitz JA, Flaker G, Garcia D, Geraldes M, Gersh BJ, Golitsyn S, Goto S, Hermosillo AG, Hohnloser SH, Horowitz J, Mohan P, Jansky P, Lewis BS, Lopez-Sendon JL, Pais P, Parkhomenko A, Verheugt FW, Zhu J, Wallentin L; ARISTOTLE Committees and Investigators: Apixaban versus warfarin in patients with atrial fibrillation. N Engl J Med 2011;365:981-992.

12 Levey AS, Coresh J, Greene T, Stevens LA, Zhang YL, Hendriksen S, Kusek JW, Van Lente F; Chronic Kidney Disease Epidemiology Collaboration: Using standardized serum creatinine values in the modification of diet in renal disease study equation for estimating glomerular filtration rate. Ann Intern Med 2006;145:247-254. Erratum in: Ann Intern Med 2008;149:519. 


\section{Kidney \\ Blood Pressure Research}

Kidney Blood Press Res 2014;39:600-608

\begin{tabular}{l|l}
\hline DOI: $10.1159 / 000368473$ & (C) 2014 S. Karger AG, Basel
\end{tabular}

Publisned onIIne: December 15, 2014

www.karger.com/kbr

13 Levey AS, Bosch JP, Lewis JB, Greene T, Rogers N, Roth D: A more accurate method to estimate glomerular filtration rate from serum creatinine: a new prediction equation. Modification of Diet in Renal Disease Study Group. Ann Intern Med 1999;130:461-470.

14 Lang RM, Bierig M, Devereux RB, Flachskampf FA, Foster E, Pellikka PA, Picard MH, Roman MJ, Seward J, Shanewise J, Solomon S, Spencer KT, St John Sutton M, Stewart W: Recommendation for the chamber quantification. Eur J Echocardiogr 2006;7:79-108.

15 Genovesi S, Pogliani D, Faini A, Valsecchi MG, Riva A, Stefani F, Acquistapace I, Stella A, Bonforte G, DeVecchi A, DeCristofaro V, Buccianti G, Vincenti A: Prevalence of atrial fibrillation and associated factors in a population of long-term hemodialysis patients. Am J Kidney Dis 2005;46:897-902.

-16 Baber U, Howard VJ, Halperin JL, Soliman EZ, Zhang X, McClellan W, Warnock DG, Muntner P: Association of chronic kidney disease with atrial fibrillation among adults in the United States: REasons for Geographic and Racial Differences in Stroke (REGARDS) Study. Circ Arrhythm Electrophysiol 2011;4:26-32.

17 Alonso A, Lopez FL, Matsushita K, Loehr LR, Agarwal SK, Chen LY, Soliman EZ, Astor BC, Coresh J: Chronic kidney disease is associated with the incidence of atrial fibrillation: the Atherosclerosis Risk in Communities (ARIC) Study. Circulation 2011;123:2946-2953.

18 Ananthapanyasut W, Napan S, Rudolph EH, Harindhanavudhi T, Ayash H, Guglielmi KE, Lerma EV: Prevalence of atrial fibrillation and its predictors in nondialysis patients with chronic kidney disease. Clin J Am Soc Nephrol 2010;5:173-181.

19 Soliman EZ, Prineas RJ, Go AS, Xie D, Lash JP, Rahman M, Ojo A, Teal VL, Jensvold NG, Robinson NL, Dries DL, Bazzano L, Mohler ER, Wright JT, Feldman HI: Chronic kidney disease and prevalent atrial fibrillation: the Chronic Renal Insufficiency Cohort (CRIC). Am Heart J 2010;159:1102-1107.

20 Camm AJ, Kirchhof P, Lip GY, Schotten U, Savelieva I, Ernst S, Van Gelder IC, Al-Attar N, Hindricks G, Prendergast B, Heidbuchel H, Alfieri O, Angelini A, Atar D, Colonna P, De Caterina R, De Sutter J, Goette A, Gorenek B, Heldal M, Hohloser SH, Kolh P, Le Heuzey JY, Ponikowski P, Rutten FH: Guidelines for the management of atrial fibrillation: the Task Force for the Management of Atrial Fibrillation of the European Society of Cardiology (ESC). Europace 2010;12:1360-1420.

21 Iung B, Baron G, Butchart EG, Delahaye F, Gohlke-Bärwolf C, Levang OW, Tornos P, Vanoverschelde JL, Vermeer F, Boersma E, Ravaud P, Vahanian A: A prospective survey of patients with valvular heart disease in Europe: the Euro Heart Survey on Valvular Heart Disease. Eur Heart J 2003;24:1231-1243.

22 Nkomo VT, Gardin JM, Skelton TN, Gottdiener JS, Scott CG, Enriquez-Sarano M: Burden of valvular heart diseases: a population based study. Lancet 2006;368:1005-1011.

23 Joint Task Force on the Management of Valvular Heart Disease of the European Society of Cardiology (ESC); European Association for Cardio-Thoracic Surgery (EACTS), Vahanian A, Alfieri O, Andreotti F, Antunes MJ, Barón-Esquivias G, Baumgartner H, Borger MA, Carrel TP, De Bonis M, Evangelista A, Falk V, Iung B, Lancellotti P, Pierard L, Price S, Schäfers HJ, Schuler G, Stepinska J, Swedberg K, Takkenberg J, Von Oppell UO, Windecker S, Zamorano JL, Zembala M: Guidelines on the management of valvular heart disease (version 2012). Eur Heart J 2012;33:2451-2496.

24 Anavekar NS, McMurray JJ, Velazquez EJ, Solomon SD, Kober L, Rouleau JL, White HD, Nordlander R, Maggioni A, Dickstein K, Zelenkofske S, Leimberger JD, Califf RM, Pfeffer MA: Relation between renal dysfunction and cardiovascular outcomes after myocardial infarction. N Engl J Med 2004;351:1285-1295.

-25 Nakagawa K, Hirai T, Takashima S, Fukuda N, Ohara K, Sasahara E, Taguchi Y, Dougu N, Nozawa T, Tanaka $\mathrm{K}$, Inoue H: Chronic kidney disease and CHADS(2) score independently predict cardiovascular events and mortality in patients with nonvalvular atrial fibrillation. Am J Cardiol 2011;107:912-916.

-26 Genovesi S, Vincenti A, Rossi E, Pogliani D, Acquistapace I, Stella A, Valsecchi MG: Atrial fibrillation and morbidity and mortality in a cohort of long-term hemodialysis patients. Am J Kidney Dis 2008;51:255262. 